\title{
Commentary: More haste, less speed
}

\author{
Luca Paolo Weltert, MD, ${ }^{\mathrm{a}}$ and \\ Michele Di Mauro, $\mathrm{MD}, \mathrm{PhD}^{\mathrm{b}}$
}

The widespread adoption of the transcatheter aortic valve implantation procedure has had major impact on the cardiovascular practice of the last years, and for good reasons The possibility of replacing a failed valve on the awake patient, with no extracorporeal circulation and no scar at all, is the holy grail of structural heart disease therapy. ${ }^{1-3}$ However, this forward acceleration heavily relies on technology, rather than technique as has traditionally happened in the past, where the incremental steps from technologic advancements played an evolutionary role in established sequence rather than being a total revolution.

The initial concerns of rapid and devastating flaw are now a thing of the past, and the technique has gained a solid reputation. ${ }^{4}$ The literature, however, is becoming populated by reports of failing devices, ${ }^{5-7}$ both at midterm (so-called structural valve deterioration) and at the early stage, such as the account in this edition of the Journal by Park and colleagues. $^{8}$ They make an important statement in commenting on their case report: as valves become thinner to accommodate smaller deployment sheath sizes, significantly higher stress at the hinge is demonstrated by many studies. On top of this, dilatation by balloon valvuloplasty poses high stress on the leaflet and hinges as well.

This report and others should induce us to consider carefully the ineludible constraints of the methodology: the dimension of the artery that serves as introduction, the dimension of the valve at its crimped stage, and the impact

\footnotetext{
From the ${ }^{\text {a Department }}$ of Cardiac Surgery, European Hospital, Rome, Italy; and the ${ }^{\mathrm{b}}$ Department of Cardiac Surgery, University of Chieti, Chieti, Italy. Disclosures: The authors reported no conflicts of interest.

The Journal policy requires editors and reviewers to disclose conflicts of interest and to decline handling or reviewing manuscripts for which they may have a conflict of interest. The editors and reviewers of this article have no conflicts of interest.

Received for publication Feb 17, 2020; revisions received Feb 17, 2020; accepted for publication Feb 20, 2020; available ahead of print March 5, 2020.

Address for reprints: Michele Di Mauro, MD, Department of Cardiac Surgery, SS Annunziata Hospital, Via dei Vestini, 66100 Chieti, Italy (E-mail: mdimauro1973@gmail.com).

JTCVS Techniques 2020;3:91

2666-2507

Copyright $(\underset{2}{ } 2020$ The Authors. Published by Elsevier Inc. on behalf of The American Association for Thoracic Surgery. This is an open access article under the CC BY-NCND license (http://creativecommons.org/licenses/by-nc-nd/4.0/).

https://doi.org/10.1016/j.xjtc.2020.02.023
}

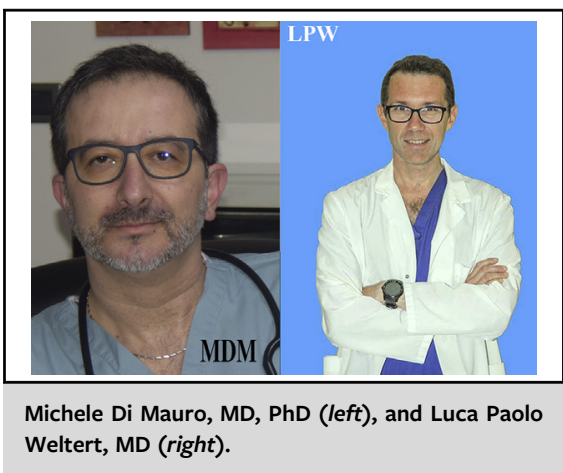

CENTRAL MESSAGE

If we really want the procedure to be consistent for our patient, careful thought should be given to optimizing implanting criteria.

of implantation trauma on the valve tissue, in terms both of acute damage and accelerated calcification. These "pillars" define the stage where the act is played and are related to physical dimensions that the actual technology has not overcome. Yet, if we really want the procedure to be consistent for our patients, careful thought about implantation criteria should probably be optimized and tailored to the individual, up to the point of having to tell some patients that they are not suitable for a safe durable implant.

\section{References}

1. Otto CM, Kumbhani DJ, Alexander KP, Calhoon JH, Desai MY, Kaul S, et al. 2017 ACC expert consensus decision pathway for transcatheter aortic valve replacement in the management of adults with aortic stenosis: a report of the American College of Cardiology Task Force on Clinical Expert Consensus Documents. J Am Coll Cardiol. 2017;69:1313-46. Erratum in: J Am Coll Cardiol. 2017;69:1362.

2. Brecker SJ, Bleiziffer S, Bosmans J, Gerckens U, Tamburino C, Wenaweser P, et al; ADVANCE Study Investigators. Impact of anesthesia type on outcomes of transcatheter aortic valve implantation (from the Multicenter ADVANCE Study). Am J Cardiol. 2016;117:1332-8.

3. Huang J, Wang S, Lu J. Awake transcatheter aortic valve replacement-an anesthesiologist's perspective. J Vis Surg. 2018;4:44.

4. Siontis GC, Praz F, Pilgrim T, Mavridis D, Verma S, Salanti G, et al. Transcatheter aortic valve implantation vs. surgical aortic valve replacement for treatment of severe aortic stenosis: a meta-analysis of randomized trials. Eur Heart J. 2016; 37:3503-12.

5. Fukuhara S, Brescia AA, Shiomi S, Rosati CM, Yang B, Kim KM, et al. Surgical explantation of transcatheter aortic bioprostheses: Results and clinical implications. J Thorac Cardiovasc Surg. January 12, 2020 [Epub ahead of print].

6. Smith D. Bioprosthetic valve durability: TAVR versus SAVR using different definitions of deterioration. Int J Cardiol. 2018;268:176-8.

7. Sawaya F, Jørgensen TH, Søndergaard L, De Backer O. Transcatheter bioprosthetic aortic valve dysfunction: what we know so far. Front Cardiovasc Med. 2019;6:145.

8. Park H, Wai Sang SL, Merhi WM. Extremely early structural failure of a self-expanding transcatheter aortic valve secondary to leaflet dehiscence. J Thorac Cardiovasc Surg Tech. 2020;3:87-8. 